\title{
HUBUNGAN PENGETAHUAN IBU TENTANG GIZI DENGAN ASUPAN ENERGI PADA ANAK STUNTING
}

\author{
Rudy Hartono, Husnal Ula, Sunarto, Agustian Ipa \\ Jurusan Gizi, Politeknik Kesehatan Kemenkes, Makassar
}

\begin{abstract}
ABSTRAK
Background The nutritional problem is essentially a public health problem that is influenced by many factors, therefore the prevention of nutritional problems can not be done by health approach but also involves other sectors such as education, religion and social. In school-age children need more energy and other nutrients such as energy, protein, calcium, fluorine and iron as the activity increases. Optimal child growth depends on the provision of nutrition with good quality and quantity as well as true. Method This research is descriptive approach with survey method that describes mother's knowledge and energy intake in child stunting Population in this research is all elementary school student of Inpres Sengka Regency of South Bontonompo Regency of Gowa. The sample of this research is class III student of class III and IV with Stunting of nutritional status A total of 26 people with measured amount of counted 62 people consisting of class III number of 11 people and IV as many as 15 people, the reason to choose class III and IV is because students Able To remember when they want direcall. Primary data consists of: a. Mother's knowledge variable is obtained from direct interview with respondent by using questionnaire instrument which contains question about causes of stunting and food energy source and so on. $b$. The variable of energy nutrient intake from child feeding habits (sample) was obtained from 2x 24 hour food recall interview method using 2x 24 hour food recall form. Assessment of nutritional intake by this method is done two days with a one-day measurement interval. Good nutrition intake if $\geq 77.0 \%$ of and less if $<77.0 \%$ AKG. c. The stunting variable was obtained by using anthropometric measurements using the TB/U indicator, the sample is said to be stunting if $\mathrm{z}$-score $<-3.0 \mathrm{SD}$ or $\mathrm{z}$-score $\geq-3.0 \mathrm{SD} \mathrm{s} / \mathrm{d}<-2.0 \mathrm{SD}$ and not stunting if $\mathrm{z}$-score $\geq-2 \mathrm{SD}$. Data types are numerical (quantitative) and data processing using statistical analysis. Data processing using computer by providing certain code which then processed with software (software) SPSS 13.0. Secondary data includes geographic and demographic data obtained from research sites and related institutions. The age data was obtained by looking at the identity of the children taken from primary school staff teachers in Sengka Subdistrict, Bontonompo District, South Gowa. Result The results showed that the mother's knowledge about good nutrition as many as 5 people $(19.2 \%)$ and less as many as 21 people $(80.8 \%)$. For a good energy intake as much as 11 people $(42.3 \%)$ and less as many as 15 people $(57.7 \%)$. As for the knowledge of mother about nutrition with energy intake that is having good knowledge of nutrition and energy intake of 1 person $(3,8 \%)$, good nutrition knowledge and energy intake less than 4 people (15,3\%) while having knowledge Less and good energy intake as much 10 people $(38,4 \%)$, knowledge of less nutrition and energy intake less than 11 people $(53,8 \%)$ and value $(p>\alpha=0,05)$ explained that there is no significant relationship between Mother's knowledge about nutrition and energy intake in elementary school stunting children. Conclusion: 1. Maternal knowledge about nutrition category less as many as 21 people $(80,7 \%)$ and good as many as 5 people $(19,23 \%)$. 2. Less energy intake in children Stunting as many as 15 people $(57.7 \%)$, good as many as 11 people $(42.3 \%)$. 3 . There is no relationship between knowledge and energy intake
\end{abstract}

Keyword : Gizi, Energi, Anak Stunting

\section{Latar Belakang}

Masalah gizi pada hakekatnya adalah masalah kesehatan masyarakat yang dipengaruhi oleh banyak faktor, oleh karena itu penanggulangan masalah gizi tidak dapat dilakukan dengan pendekatan kesehatan saja akan tetapi juga melibatkan sektor lain seperti pendidikan, agama dan sosial (supariasa, 2002).

Pada anak usia sekolah membutuhkan lebih banyak energi dan zat gizi lain seperti energi, protein, kalsium, fluor dan zat besi seab aktifitas yang kian bertambah. Tumbuh kembang anak yang optimal tergantung pemberian nutrisi dengan kualitas dan kuantitas yang baik serta benar (sartika, 2010).

Lebih dari sepertiga $(36,1 \%)$ anak indonesia tergolong stunting ketika masuk sekolah dan hal ini merupakan indikasi gangguan kurang gizi kronis. Prevalensi anak stunting semakin meningkat dan berkembang dengan bertambahnya usia, baik pada anak perempuan maupun pada anak laki-laki (Aritonang, 2010).

Data Riset Kesehatan Dasar (RISKESDAS) tahun 2010 di Provinsi Sulawesi Selatan untuk kategori sangat pendek $15,8 \%$ dan pendek 23,1\%, stunting 38,9\% (Balitbangkes, 2010). Data Riskesdas 2013 prevalensi stunting umur 5-12 tahun di Provinsi Sulawesi Selatan untuk kategori sangat pendek $10,8 \%$ dan pendek $23,2 \%$, jadi prevalensi stunting di Provinsi Sulawesi Selatan Sebesar 34\% (Balitbangkes, 2013). Data stunting kabupaten Gowa Provinsi Sulawesi Selatan umur 5-12 tahun untuk kategori sangat pendek $16,4 \%$ dan pendek $17,4 \%$, sehingga prevalensi stunting 33,8\% (Balitbangkes, 2013).

Prevalensi stunting pada anak sekolah di Indonesia secara nasional tahun 2007 sebesar $36,8 \%$ (Balitbangkes, 2007). Prevelensi stunting umur 5-12 tahun di Indonesia sebesar 35,1\% terdiri dari $15,1 \%$ sangat pendek dan $20 \%$ pendek, masih tidak jauh berbeda dengan anak balita (Balitbangkes, 2010). Prevalensi stunting umur 512 tahun di Indonesia sebesar 30,7\% terdiri dari $12,3 \%$ sangat pendek, dan pendek $18,4 \%$ (Balitbangkes, 2013).

Pengetahuan ibu tentang gizi sangat penting, hal ini disebabkan untuk menciptakan generasi masa depan yang lebih baik, peran ibu dalam merawat anak menjadi faktor penentu. Kesadaran akan pentingnya pemberian gizi yang 
baik terkadang belum sepenuhnya dimengerti. Adapun orang tua yang sudah mengetahui tentang gizi tetapi tidak diterapkan dalam kehidupan dan adapula yang tidak mengetahuinya sama sekali. Kebutuhan gizi yang kurang akan menyebabkan kekurangan gizi bahkan dapat menyebabkan kematian apabila dibiarkan secara terus menerus.

Faktor yang mempengaruhi status gizi diantaranya adalah asupan zat gizi, pola pengasuhan anak, dan pendapatan keluarga, pada salah satu penelitian didapat hasil akhir pengetahuan tentang gizi dalam kategori kurang sebesar $53,13 \%$ sedangkan pengetahuan gizi ibu pada kategori baik sebesar 46,87, hal tersebut menunjukan banyak ibu yang masih kurang dalam pengetahuan tentang gizi (Nurhikmah 2011).

Stunting pada masa anak-anak berhubungan dengan perkembangan kognitif, produktifitas yang rendah beresiko pendek pada masa dewasa. Total prevalensi anak usia sekolah $35,4 \%$, dan faktor yang berhubungan dengan stunting dengan status gizi pada anak usia sekolah adalah pekerjaan, pendidikan/pengetahuan ibu (Salimar dkk 2013).

Dalam masa tumbuh kembangnya anak usia sekolah pemberian nutrisi atau asupan zat gizi tidak selalu dapat dilaksanakan dengan sempurna. Banyak sekali masalah yang ditimbulkan dalam pemeberian manan yang tidak benar dan menyimpang, penyimpangan ini mengakibatkan gangguan pada banyak organ dan sistem tubuh anak (Judarwanto, 2006).

Survey awal yang dilakukan peneliti di SD Inpres Sengka Kecamatan Bontonompo Kabupaten Gowa, jumlah anak yang diukur yaitu 62 orang dan tergolong pendek sebanyak $34,5 \%$ dan sangat pendek sebanyak $8,0 \%$. Jadi jumlah anak yang mengalami stunting sebanyak 43,5\%.

Berdasarkan uraian diatas, maka peneliti tertarik untuk meneliti hubungan pengetahuan ibu tentang gizi dan asupan energi pada anak sekolah dasar yang stunting.

\section{METODO PENELITIAN}

Jenis Penelitian ini adalah pendekatan deskriptif dengan metode survei yaitu mendeskripsikan pengetahuan ibu dan asupan energi pada anak stunting.

Populasi pada penelitian ini adalah seluruh anak sekolah dasar Inpres Sengka Kecamatan Bontonompo Selatan Kabupaten Gowa, Sampel penelitian ini adalah anak sekolah dasar kelas III dan IV dengan status gizi stunting sebanyak 26 orang dengan jumlah anak yang diukur sebanyak 62 orang yang terdiri dari jumlah kelas III sebanyak 11 orang dan IV sebanyak 15 orang, alasan memilih kelas III dan IV adalah karena siswa sudah mampu mengingat kembali saat hendak direcall .

Data primer terdiri dari : a. Variabel pengetahuan ibu yang diperoleh dari hasil wawancara langsung terhadap responden dengan menggunakan instrumen kuesioner yang berisi pertanyaan tentang penyebab stunting dan makanan sumber energi dan lain sebagainya. b. Variabel asupan zat gizi energi dari kebiasaan makan anak (sampel) yang diperoleh dari metode wawancara food recall $2 \times 24$ jam dengan menggunakan instrumen form food recall $2 \mathrm{x} 24$ jam. Penilaian asupan zat gizi dengan metode ini dilakukan dua hari dengan selang satu hari pengukuran. Asupan zat gizi dikatan baik jika $\geq 77,0 \%$ dari dan kurang jika $<77,0 \%$ dari AKG. c. variabel stunting diperoleh denga cara pengukuran antropometri menggunakan indikator TB/U, sampel dikatakan stunting jika $\mathrm{z}$-score $<-3,0 \mathrm{SD}$ atau $\mathrm{z}$-score $\geq-3,0$ SD s/d $<-2,0$ SD dan tidak stunting jika z-score $\geq$ 2 SD. Jenis data adalah numerik (kuantitatif) dan pengolahan data dengan menggunakan analisis statistik. Pengolahan data menggunakan komputer dengan memberikan kode-kode tertentu yang kemudian diolah dengan perangkat lunak (software) SPSS 13.0.

Data sekunder meliputi data geografi dan demografi yang diperoleh dari lokasi penelitian dan instansi yang terkait. Data umur diperoleh dengan melihat identitas anak yang diambil dari guru staf yaitu siswa SD Inpres Sengka Kecamatan Bontonompo Selatan Kabupaten Gowa

\section{A. Hasil penelitian}

1. Gambaran Umum Lokasi Penelitian SD Inpres Sengka yaitu sekolah di Desa Sengka Kecamatan Bontonompo Selatan Kabupaten Gowa. Memiliki 6 ruang kelas, 1 ruang kepala sekolah, 1 perpustakaan dan 190 orang siswa mulai dari kelas 1 sampai 6 .

Jumlah guru yaitu 13 orang termasuk kepala sekolahKrakteristik Sampel

2. Karakteristik sampel

Data pengetahuan ibu tentang gizi, dengan asupan energi diteliti mulai tgl 13 Juli 2017. Pada penelitian ini pada siswa kelas III dan IV sebanyak 26 siswa yang stunting. Adapun krakteristik dapat di bawah pada tabel 01 \& 02 . 
a. Jenis kelamin

Tabel 01

Distribusi berdasarkan jenis kelamin di Sekolah Dasar Inpres Sengka Kecamatan Bontonompo Selatan Kabupaten Gowa Tahun 2017

\begin{tabular}{ccc}
\hline \hline Jenis kelamin & $\mathrm{N}$ & $\%$ \\
\hline Laki-laki & 12 & 46,2 \\
\hline Perempuan & 24 & 53,8 \\
\hline Total & 26 & 100 \\
\hline \hline
\end{tabular}

\section{Sumber Data Primer 2017}

Berdasarkan tabel 01 menunjukan bahwa jenis kelamin sampel laki-laki sebanyak 12

b. Kelas orang $(46,2 \%)$ dan perempuan sebanyak 24 orang $(53,8 \%)$.

Tabel 02

Distribusi sampel berdasarkan kelas di Sekolah Dasar Inpres Sengka Kecamatan Bontonompo Selatan Kabupaten Gowa

Tahun 2017

\begin{tabular}{ccc}
\hline \hline Kelas & $\mathrm{N}$ & $\%$ \\
\hline 3 & 11 & 42,3 \\
\hline 4 & 15 & 57,7 \\
\hline Total & 26 & 100 \\
\hline \hline
\end{tabular}

Sumber Data Primer 2017

Berdasarkan tabel 02 menunjukan kelas 3 sebanyak 11 orang $(42,3 \%)$ dan kelas 4 sebanyak 15 orang $(57,7 \%)$.

c. Pengetahuan ibu tentang gizi

Tabel 03

Distribusi sampel berdasarkan pengetahuan ibu tentang gizi di Sekolah Dasar Inpres Sengka Kecamatan Bontonompo Selatan Kabupaten Gowa

Tahun 2017

\begin{tabular}{ccc}
\hline \hline Pengetahuan gizi & $\mathrm{N}$ & $\%$ \\
\hline Baik & 5 & 19,2 \\
\hline Kurang & 21 & 80,8 \\
\hline Total & 26 & 100 \\
\hline \hline
\end{tabular}

Sumber Data Primer 2017

Beradasarkan tabel 03 menunjukkan bahwa yang memiliki pengtahuan yang baik sebanyak 5 orang $(19,2 \%)$ dan yang pengetahuan gizi yang kurang sebanyak 21 orang $(80,8 \%)$. 
Tabel 04

Distribusi sampel berdasarkan asupan energi di Sekolah Dasar Inpres Sengka Kecamatan Bontonompo Selatan Kabupaten Gowa

Tahun 2017

\begin{tabular}{ccc}
\hline \hline Asupan energy & $\mathrm{N}$ & $\%$ \\
\hline Baik & 11 & 42,3 \\
\hline Kurang & 15 & 57,7 \\
\hline Total & 26 & 100 \\
\hline \hline
\end{tabular}

Sumber Data Primer 2017

Berdasarkan tabel 04 menunjukan bahwa asupan energi murid yang baik sebanyak 11 orang $(42,3 \%)$ dan yang kurang sebanyak 15 orang $(57,7 \%)$.

e. Hubungan pengetahuan gizi ibu dengan asupan energi

Tabel 05

Distribusi berdasarkan pengetahuan gizi dengan asupan energi di di Sekolah Dasar Inpres Sengka Kecamatan Bontonompo Selatan Kabupaten Gowa

Tahun 2017

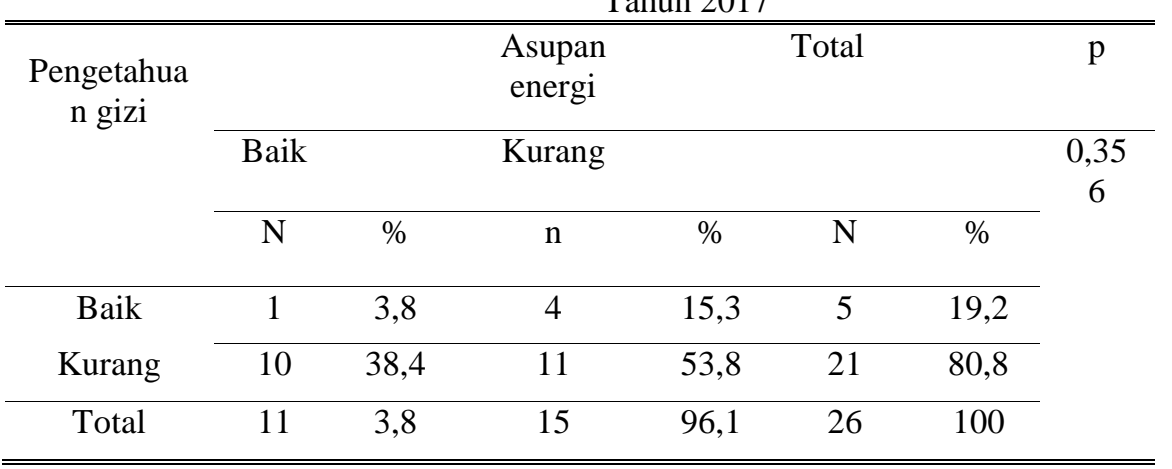

Sumber Data Primer 2017

Tabel 05 menunjukan bahwa dari 26 sampel, yang asupan energi baik memiliki pengetahuan gizi yang baik sebanyak 1 orang $(3,8 \%)$, yang memiliki pengetahuan gizi yang baik asupan energinya kurang sebanyak 4 orang $(15,3 \%)$, yang memiliki pengetahuan gizi kurang asupan energinya baik 10 orang $(34,8 \%)$, dan yang memiliki pengetahuan gizi kurang asupan energinya kurang sebanyak 11 orang $(53,8 \%)$. Hasil uji statistik hubungan antara pengetahuan dengan asupan energi $\quad(p=0,356>\alpha=0,05)$ menjelaskan bahwa tidak ada hubungan yang signifikan antara pengetahuan ibu tentang gizi dan asupan energi pada anak SD stunting

\section{PEMBAHASAN}

1. Pengetahuan ibu tentang gizi Berdasarkan penelitian diperoleh pengetahuan ibu yang baik sebanyak 5 orang $(19,2 \%)$ dan yang memiliki pengetahuan yang kurang sebanyak 21 orang $(80,8 \%)$. Hal ini berbanding lurus dengan dengan penelitian Susmi Akhriani tahun 2013 yaitu dari sampel 31 sampel, 24 orang $(76,4 \%)$ diantaranya memiliki pengetahuan yang kurang dan 7 orang $(23,6 \%) \quad$ memiliki pengetahuan yang baik, salah satu penyebab yang menjadi tolak ukurny adalah ibu dari anak yang stunting sedikit banyaknya makanan yang baik untuk anakanak mereka hanya saja mereka kurang mengetahui istilah-istilah dalam dunia gizi yang lebih dalam semisal istilah Karbohidrat 
Untuk beras, protein untuk telur adapaun penyebab langsung dari kurangnya pengetahuan pada ibu yang memiliki anak stunting menurut Unicef 1998 ialah ada dua yaitu penyebab langsung dan tidak langsung. Adapaun penyebab tidak langsungnya yaitu sanitasi, pola asuh, ketersediaan pangan dan penebab langsungnya yaitu makanan tidak seimbang dan penyakit infeksi ( Unicef 1998 dam Siti Uswatun Hasanah, 2014).

Pengetahuan gizi adalah segala sesuatu tetang gizi yang diketahui yang mampu diingat oleh setiap individu, setelah melihat atau menyaksikan, diajarakan kepadanya. Hakikatnya pengetahuan diperoleh melalui proses belajar yaitu suatu proses perubahan tingkah laku yang dinyatakan dalam pengenalan, penguasaan, penggunaan dan penilaian terhadap bidang tertentu yang berhubungan dari berbagai aspek kehidupan, kondisi yang diketahui sekrang ini, pengetahuan tentang gizi masih kurang. Pengetahuan merupakan hasil dari tahu, dan ini terjadi seelah orang melakukan pengindraan terjadi melalui panca indra manusia, yakni indra penghlihatan, penciuman, rasa dan raba sebagian besar pengetahuan manusia diperoleh melalui mata dan telinga (Notoadmojo, 2007).

Tingkat pengetahuan gizi ibu sangat menentukan apa dan bagaimana ibu memberikan makanan sesuai dengan kebutuhan anaknya. Gizi kurang tidak hanya terjadi akibat ekonomi yang kurang, tetapi juga karena kurangnya pengetahuan tentang gizi. Tingginya tingkat pengetahuan gizi pada ibu akan banyak membantu menentukan tindak lanjut dalam berbabagai masalah seperti pemilihan dan penyediaan makanan yang beraneka ragam (Moehji, 2003).

2. Asupan energi

Berdasarkan penelitian diperoleh asupan energi yang baik sebanyak 11 orang (42,3\%), yang kurang sebanyak 15 orang $(57,7 \%)$ hasil penelitian yang dilakukan pada anak SD Inpres Sengka Kecamatan Bontonompo Selatan Kabupaten Gowa. Hal ini berbanding lurus dengan penelitian Irna Yulianti tahun 2014 di SDIT Al-insyirah Pacerakkang yaitu dari sampel 72 orang yang memiliki asupan baik sebanyak 6 orang $(8,3 \%)$, asupan kurang sebanyak 66 orang $(91,7 \%)$ dan hasil penelitian dari Nuryani tahun 2013 dengan jumlah sampel 43 orang anak SDN Pajjaiang yaitu asupan energi yang kurang sebanyak 26 orang $(60,5 \%)$, asupan baik sebanyak 16 orang $(37,2 \%)$, yang lebih sebanyak 1 orang $(2,3 \%)$. Berdasarkan Riset Kesehatan Dasar (Riskesdas) tahun 2010 di Makassar, sebanyak $40,6 \%$ penduduk konsumsi energi di bawah $70 \%$ dari angka kecukupan gizi (AKG) dan salah satunya terdapat pada anak usia sekolah yakni 44,2\%.

Adapun akibat dari kurangnya asupan zat gizi dapat mempengaruhi status gizi anak dan menimbulkan berbagai masalah gizi diantaranya KVA, GAKY, Anemia, KEP serta dapat mempengaruhi pertumbuhan dan kesehatan fisik anak.

3. Hubungan antara pengetahuan dengan asupan energy Berdasarkan hasil analisis dengan meggunakan uji chi-square pada variabel pengetahuan dengan asupan energi menunjukan bahwa tidak ada hubungan yang signifikan ( $\mathrm{p}>$ 0,05). Hal ini tidak sejalan dengan teori yang menyatakan bahwa tingkat pengetahuan gizi seseorang berpengaruh terhadap sikap dan perilaku dalam pemilihan makanan dan selanjutnya akan berpengaruh pada keadaan gizi individu yang bersankutan. Keadaan gizi yang rendah sapa suatu wilayah akan menentukan tingginya angka prevalensi kurang gizi secara nasional. Pengetahuan gizi yang 
kurang atau kurangnya menerapkan pengetahuan gizi alam keadaan hidup sehari-hari dapat menimbulkan masalah gizi (Rosa, 2011).

Pengetahuan gizi sangat diperlukan untuk membentuk perilaku positif dalam hal memenuhi kebutuhan gizi sebagai salah satu unsur penting yang mendukung status kesehatan seseorang. Pendidikan kesehatan yang berkaitan dengan pengetahuan gizi dilakukan untuk menghasilkan perilaku yang dibutuhkan untuk memelihara, mempertahankan, ataupun meningkatkan keadaan gizi yang baik. Anak sekolah yang mendapat asupan energi akan memiliki cukup tenaga untuk melakukan aktivitas seperti bermain, belajar, serta pertumbuhannya. Beberapa contoh perilaku yang hendak diwujudkan dalam menghasilkan perilaku yang mendukung tercapainya gizi yang baik salah satunya yaitu setiap keluarga wajib menerapkan pola menu seimbang dalam konsumsi makanan sehari-hari sehingga dapat mencapai pertumbuhan yang optimal (Sulistyoningsih 2011).

\section{Kesimpulan}

1. Pengetahuan ibu tentang gizi kategori kurang sebanyak 21 orang $(80,7 \%)$ dan yang baik sebanyak 5 orang $(19,23 \%)$.

2. Asupan energi yang kurang pada anak Stunting sebanyak 15 orang $(57,7 \%)$, yang baik sebanyak 11 orang $(42,3 \%)$.

3. Tidak ada hubungan antara pengetahuan dan asupan energi.

\section{DAFTAR PUSTAKA}

Aritonang, Irianto. (2010). Menilai Status Gizi Untuk Mencapai Sehat Optimal. Jakarta; Grafina Mediacipta.

Balitbangkes. (2007). Riset Kesehatan Dasar Nasional. Jakarta. Depertemen Kesehatan Republik Indonesia.
Balitbangkes. (2013). Riset Kesehatan Dasar Nasional. Jakarta. Depertemen Kesehatan Republik Indonesia.

Balitbangkes. (2010). Riset Kesehatan Dasar (RISKESDAS) Laporan Provinsi Sulawesi Selatan. Badan Penelitian dan Pengembangan Kesehatan : Depertemen Kesehatan Republik Indonesia. Jakarta.

Balitbangkes. (2013). Riset Kesehatan Dasar (RISKESDAS) Laporan Kabupaten Gowa Provinsi Sulawesi Selatan. Badan Penelitian dan Pengembangan Kesehatan : Depertemen Kesehatan Republik Indonesia. Gowa.

Irna Yulianti. 2014. Gambaran Asupan Zat Gizi dan Prestasi Belajar Anak di Sekolah Dasar Islam Terpadu (Sdit) Al-Isyirah Pacerakkang. Politeknik Kesehatan Makassar. KTI.

Judarwanto W. 2006. Antisipasi Perilaku Makan Anak di Sekolah. http://www..pdpersi.co.id. (diakses, 25 Februari 2015).

Moehji, S. 2003. Ilmu Gizi 2 Penanggulangan Gizi Buruk. Jakarta : Papas Sinar Sinant.

Nurhikmah. 2011. Hubungan pengetahuan dan Asupan Zat Gizi dengan Status Gizi Ibu Hamil di Puskesmas Kassi-Kassi Kota Makassar Politeknik Kesehatan Makassar. KTI.

Nuryani. 2013. Gambaran Asupan Energi dan Protein dengan Prestasi Blajar Anak Sekolah Dasar di SDN Pajjaiang Kelurahan Sudiang Raya Kec.Biringkanaya Kota Makassar. Poltiknik Kesehatan Makassar. KTI.

Notoadmojo, S. 2007. Pengantar Pendidikan Kesehatan dan Ilmu Perilaku Kesehatan. Andi Offset. Yogyakarta.

Rosa, Revida. 2011. Pengetahuan Gizi dan Keamanan Pangan Jajanan Serta Kebiasaan Jajan Siswa Sekolah Dasar Di Depok dan Sukabumi(Skripsi). Bogor : Institusi Pertanian Bogor.

Salimar, dkk. 2013. Stunting Anak Usia Sekolah Di Indonesia Menurut Karakteristik Keluarga (diakses 2 Desember 2013). 
Siti Uswatun Hasanah, 2014 Hubungan Pola Asuh dan Zat Gizi pada Baduta stunting dan atau wasting di Kelurahan Allepolea Kecamatan Lau Kabupaten Maros Politeknik Kesehatan Makassar. KTI

Sulistyoningsih Haryani. (2011). Gizi untuk Kesehatan Ibu dan Anak. edisi pertamayogyakarta; graha ilmu.
Supariasa, I. D. N, dkk, (2002). Penelian Status Gizi. Jakarta; Buku Kedokteran EGC.

Susmi Akhriani, 2013 Gambaran Karakteristik Orang Tua dan Asupan Energi Pada Anak Stunting di SDN 258 Sakui-Sakui Kecamatan Bontotiro Kabupaten Bulukumba Politeknik Kesehatan Makassar. KTI 